\title{
Emodin affects ERCC1 expression in breast cancer cells
}

\author{
Jian-min Fu' ${ }^{*}$, Jie Zhou', Jian Shi', Jian-sheng Xie ${ }^{1}$, Li Huang ${ }^{1}$, Adrian YS Yip ${ }^{2}$, Wings TY Loo ${ }^{2}$, Louis WC Chow ${ }^{2}$, \\ Elizabeth LY Ng${ }^{2}$
}

From Organisation for Oncology and Translational Research (OOTR) 7th Annual Conference Hong Kong. 13-14 May 2011

\begin{abstract}
Background: Multi-drug resistance to chemotherapeutic agents is a major cause of treatment failure in breast cancer. In this study, we investigated the effects of emodin on reversing the multi-drug resistance, examined the ERCC1 protein expression in breast cancer cell line, and explored the relationship between reversal of multi-drug resistance and ERCC1 protein expression.

Methods: MTT assay was conducted to test the cytotoxicity of adriamycin and cisplatin to MCF-7/Adr cells with and without emodin pretreatment, and Western blot was performed to examine the ERCC1 protein expression.

Results: MCF-7/Adr cells had 21-fold and 11-fold baseline resistances to adriamycin and cisplatin, respectively. When emodin was added to the cell culture at the concentration of $10 \mu \mathrm{g} / \mathrm{ml}$, the drug resistance was reduced from 21 folds to 2.86 folds for adriamycin, and from 11 folds to 1.79 folds for cisplatin. MCF-7/Adr cells treated with two concentrations $(10 \mu \mathrm{g} / \mathrm{mL}$ and $20 \mu \mathrm{g} / \mathrm{mL})$ of emodin, after 2, 4, 6, 10 days, the trend of ERCC1 expression was gradually decreased and the reduction was more obvious comparatively at the concentration of $20 \mu \mathrm{g} / \mathrm{mL}$.
\end{abstract}

Conclusions: Emodin could reverse the multi-drug resistance in MCF-7/Adr cells and down-regulate ERCC1 protein expression.

\section{Background}

Excision repair cross complementation group 1 (ERCC1) protein encoded by $E R C C 1$ gene is a key player in nucleotide excision repair (NER), and our previous work and others have demonstrated that this protein is also expressed in breast cancer [1,2]. The NER system represented by ERCC1 is extensively involved in human cell DNA repair after damage, but over-expression of ERCC1 can lead to multi-drug resistance to chemotherapy in cancer treatment $[3,4]$.

In recent years, the expression of ERCC1 was extensively studied in endometrial cancer [5], ovarian cancer [6], non-small cell lung cancer [7-9], nasopharyngeal cancer [10] and thymic cancer [11]. It was deemed to predict response to anti-cancer treatment and possibly have a

\footnotetext{
* Correspondence: jmfu2000@yahoo.com.cn

'Department of Breast Disease, Shenzhen Maternity and Child Healthcare

Hospital, Southern Medical University, Shenzhen, China

Full list of author information is available at the end of the article
}

prognostic role. According to the latest systematic review of predictive value of multidrug resistance-associated proteins (MDR1, MRP1, MRP2 and MVP), topoisomerase II and ERCC1, ERCC1 was a promising predictive marker for survival in some patients [12]. However, the study of ERCC1 in breast cancer is limited. Kim [13] found that ERCC1 expression is low in triple-negative breast cancer subtypes, but the relationship with survival is still unknown. ERCC1 might have its roles in DNA repair systems in breast cancer, but its contribution to drug resistance remains unclear.

Emodin (EMD) is a natural anthraquinone compound extracted from the rhizome of rhubarb. The traditional Chinese medicinal herb was widely used for treatment of various ailments and the anti-cancer activity of EMD was demonstrated in some studies [14-16]. The ability to reverse the multi-drug resistance to cancer chemotherapeutic agents was also shown in previous pharmacological studies $[17,18]$. In this in vitro study, multi-drug
C Biomed Central

(c) 2012 Fu et al; licensee BioMed Central Ltd. This is an Open Access article distributed under the terms of the Creative Commons Attribution License (http://creativecommons.org/licenses/by/2.0), which permits unrestricted use, distribution, and reproduction in any medium, provided the original work is properly cited. 
resistant breast cancer cell line MCF-7/Adr was exposed to different levels of EMD. Drug sensitivity and ERCC1 expression were studied, so as to explore the role of ERCC1 in breast cancer multi-drug resistance and the effect of EMD on reversing such resistance.

\section{Methods}

\section{Drugs and reagents}

Adriamycin (ADM, Haizheng Pharmaceuticals Co., Ltd, Zhejiang, China.), cisplation (DDP, Nanjing Pharmaceuticals Co., Ltd, Jiangsu, China), Emodin (EMD, China National Institute for the Control of Pharmaceutical and Biological Products, Beijing China), cell culture medium RPMI-1640 (GIBCO,USA), methyl thiazolyl tetrazolium (MTT) assay kit (Sigma,USA), mouse anti-human ERCC1 monoclonal antibody (Santa Cruz,USA), horseradish peroxidase-labeled goat anti-mouse secondary antibody (Sigma,USA) were all commercially obtained. ADM and EMD were reconstituted with sterile injection water to make $2 \mathrm{mg} / \mathrm{ml}$ and $20 \mathrm{mg} / \mathrm{ml}$ stock solutions, respectively; and DDP was reconstituted with normal saline solution to make $5 \mathrm{mg} / \mathrm{dl}$ stock solution. All the stock solutions were divided in appropriate aliquots and kept in $4^{\circ} \mathrm{C}$ refrigerator. Application solutions were made immediately before use by adding culture medium.

\section{Cell lines}

Multi-drug resistant breast cancer cell line MCF-7/Adr and its drug sensitive parent cell line MCF-7 were obtained from Guangzhou DaHui Biotech Co., Ltd. China. The cells were cultured in RPMI-1640 medium supplemented with $10 \%$ fetal bovine serum, penicillin $100 \mathrm{U} / \mathrm{ml}$ and streptomycin $100 \mu \mathrm{g} / \mathrm{m} 1$, in $5 \% \mathrm{CO}_{2}$, saturated humidity, $37^{\circ} \mathrm{C}$ incubator. The cells show adherent growth. In vitro study was conducted when the cells reach logarithmic growth phase.

\section{MTT assay}

Cells at logarithmic growth phase were seeded on 96-well culture plates, with $6 \times 10^{3}$ cells in each well. After 24 hours of culture, the cells were evenly attached to the bottom of the plate. ADM, DDP and EMD of 5 concentration gradients were added. After 72 hours, the medium was removed, $100 \mu \mathrm{l}$ of MTT reagent $(5 \mathrm{mg} / \mathrm{ml})$ was added to each well, and the plate was cultured for another 4 hours. Then the MTT solution was removed, $200 \mu \mathrm{l}$ of dimethyl sulphoxide (DMSO) was added. The plate was shaken for 15 minutes to fully dissolve the MTT. Absorbance in each well was determined at 490 $\mathrm{nm}$ with enzyme-linked immunoassay detector. Cell viability was determined according to the follow equation: Cell survival rate $=$ (absorbance in the drug test group $/$ absorbance in control group) $\times 100 \%$.

\section{Calculation and statistical analysis}

The $50 \%$ lethal concentration $\left(\mathrm{IC}_{50}\right)$ was calculated according to Reed-Muench formula and expressed as mean $\pm \mathrm{SD}$. The drug resistance $=\left(\mathrm{IC}_{50}\right.$ of MCF-7/Adr $) \div$ $\left(\mathrm{IC}_{50}\right.$ of MCF-7). Drug resistance reversal $=\left(\mathrm{IC}_{50}\right.$ of MCF$7 /$ Adr cultured without EMD $) \div\left(\mathrm{IC}_{50}\right.$ of MCF-7/Adr cultured with EMD).

\section{ERCC1 expression by Western blotting}

MCF-7 and MCF-7/Adr cells at logarithmic growth phase were seeded into 6 -well plate with $1.2 \times 10^{4}$ cells in each well. MCF-7 cells in the first well were used as negative control. MCF-7/Adr cells in the second well were used as blank control. MCF-7/Adr cells in the other 4 wells were exposed to $10 \mu \mathrm{g} / \mathrm{ml}$ and $20 \mu \mathrm{g} / \mathrm{ml}$ of EMD. After cell culture for 2, 4, 6 and 10 days, the cells were harvested, and total cell protein was extracted after cell-lysis. The cell protein was subjected to sodium dodecyl sulphate polyacrylamide gel electrophoresis (SDS-PAGE). The separated proteins were transferred to nitrocellulose membrane. After blocking in 5\% skim milk for 1.5 hours, the membrane was incubated with mouse anti-human ERCC1 monoclonal antibody overnight, and then horseradish peroxidase-labeled goat anti-mouse secondary antibody for 2 hours. After washing, the film was developed in darkroom per protocol.

\section{Results}

When MCF-7 and MCF-7/Adr cells were exposed to $\mathrm{ADM}$ gradient solutions, the $\mathrm{IC}_{50}$ of MCF-7/Adr was 21 times higher than MCF-7 $(8.75 \pm 0.39 \mu \mathrm{g} / \mathrm{ml} v s .0 .41 \pm$ $0.11 \mu \mathrm{g} / \mathrm{ml}, P<0.01$ ) (Figure 1). When MCF-7 and MCF-7/Adr cells were exposed to DDP gradient solutions, the $\mathrm{IC}_{50}$ of MCF-7/Adr was 11 times higher than MCF-7 $(6.34 \pm 0.32 \mu \mathrm{g} / \mathrm{ml}$ vs. $0.56 \pm 0.13 \mu \mathrm{g} / \mathrm{ml}$, $P<0.01$ ) (Figure 2). After exposure to EMD at various concentrations, the $\mathrm{IC}_{50}$ was $100 \pm 0.35 \mu \mathrm{g} / \mathrm{ml}$ for

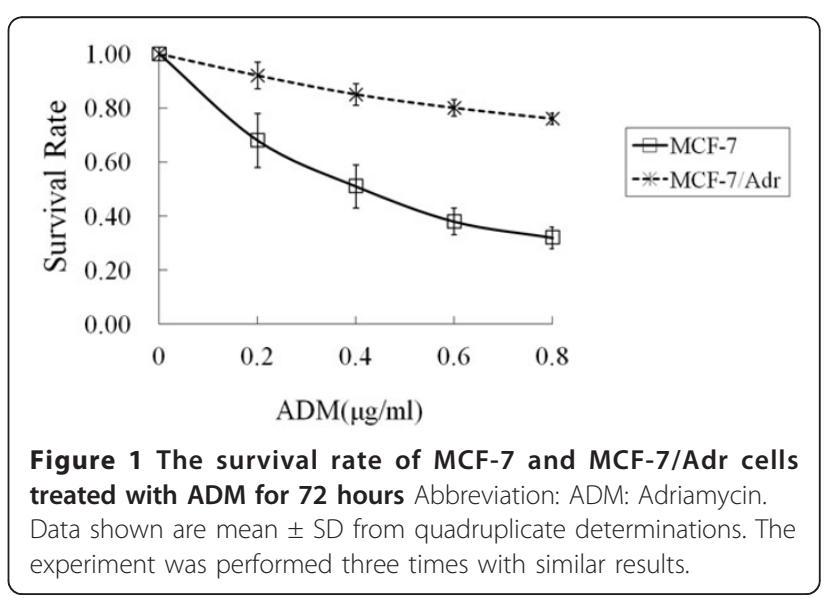




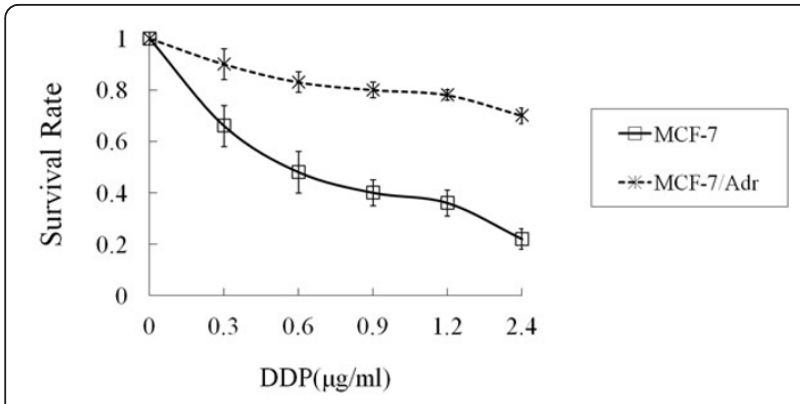

Figure 2 The survival rate of MCF-7 and MCF-7/Adr cells treated with DDP for $\mathbf{7 2}$ hours Abbreviation: DDP: Cisplatin. Data shown are mean \pm SD from quadruplicate determinations. The experiment was performed three times with similar results

MCF-7 and $79 \pm 0.28 \mu \mathrm{g} / \mathrm{ml}$ for MCF-7/Adr $(P>0.05)$ (Figure 3).

For MCF-7/Adr cells, the ADM IC $\mathrm{I}_{50}$ was reduced from $8.75 \pm 0.39 \mu \mathrm{g} / \mathrm{ml}$ without EMD treatment to 3.06 $\pm 0.26 \mu \mathrm{g} / \mathrm{ml}$ after treatment with $10 \mu \mathrm{g} / \mathrm{ml}$ EMD $(P<$ 0.01). EMD had a 2.86-fold reversal of ADM IC ${ }_{50}$ for MCF-7/Adr cells (Figure 4). For MCF-7/Adr cells, the DDP $\mathrm{IC}_{50}$ was reduced from $6.34 \pm 0.32 \mu \mathrm{g} / \mathrm{ml}$ without EMD treatment to $3.54 \pm 0.28 \mu \mathrm{g} / \mathrm{ml}$ after treatment with $10 \mu \mathrm{g} / \mathrm{ml}$ EMD $(P<0.05)$. EMD had a 1.79 -fold reversal of $\mathrm{ADM} \mathrm{IC} \mathrm{I}_{50}$ for MCF-7/Adr cells (Figure 5). However, the change in $\mathrm{IC}_{50}$ of both $\mathrm{ADM}$ and DDP was not statistically significant after treatment with EMD.

The baseline ERCC1 expression was higher in MCF-7/ Adr cells than MCF-7 cells. When MCF-7/Adr cells were treated with EMD treatment at $10 \mu \mathrm{g} / \mathrm{ml}$ for 2, 4, 6 and 10 days, ERCC1 expression progressively decreased. Significantly greater inhibition of ERCC1 expression was evident when the cells were exposed to $20 \mu \mathrm{g} / \mathrm{ml}$ of EMD for 2, 4, 6 and 10 days. At each time point, EMD at $20 \mu \mathrm{g} / \mathrm{ml}$ shows a higher inhibitiory effect (Figure 6).

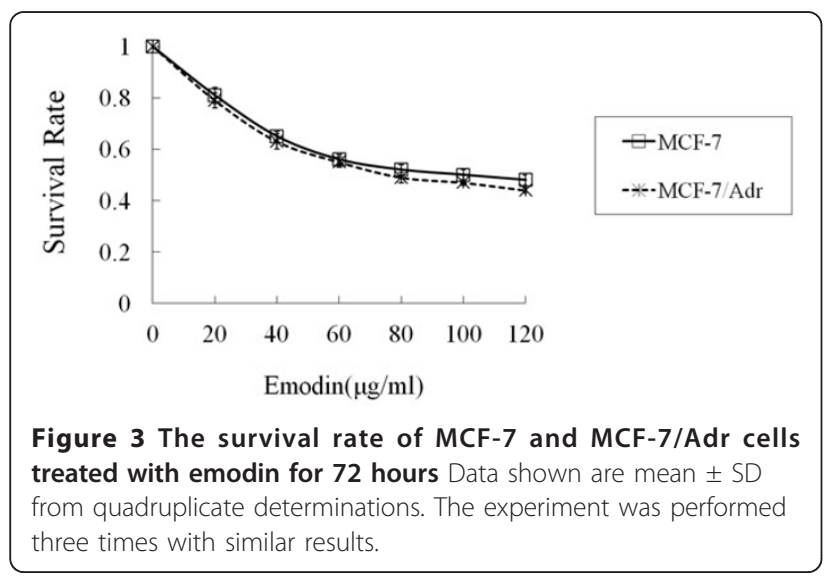

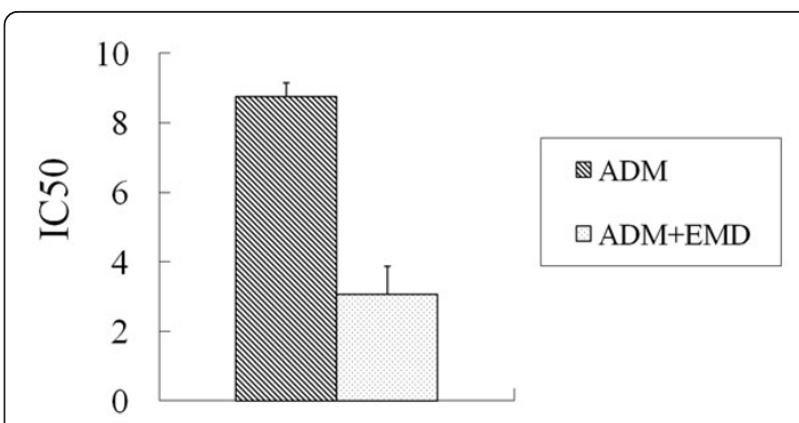

Figure 4 The IC50 of ADM with and without emodin for MCFF/Adr cells ADM: Adriamycin

Baseline ERCC1 expression was lower in MCF-7 (negative control, Lane 1) than in MCF-7/Adr (blank control, Lane 2). When MCF-7/Adr cells were exposed to EMD $(10 \mu \mathrm{g} / \mathrm{ml})$ for 2 (Lane 3), 5 (Lane 5), 6 (Lane 7) and 10 (Lane 9) days, ERCC1 expression was progressively inhibited. When MCF-7/Adr cells were exposed to $20 \mu \mathrm{g} / \mathrm{ml}$ of EMD, significantly greater inhibition was also observed at each time point (Lanes 4, 6, 8 and 10).

\section{Discussion}

Multi-drug resistance to chemotherapeutic agents is a major cause of treatment failure in breast cancer, because chemotherapy plays ever increasing role in the systemic treatment modalities of breast cancer both in neoadjuvant and adjuvant chemotherapy $[19,20]$. For patients who cannot obtain clinical remission during adjuvant chemotherapy and those with recurrence and metastasis after initial treatment, reversal of multi-drug resistance is of crucial importance for improving clinical outcome $[21,22]$. After resection of the primary tumor, there is no validated clinical parameter to predict the sensitivity to chemotherapy. Therefore, it is essential to explore the molecular mechanisms of multi-drug resistance and the reversal strategy are very important in breast cancer treatment [23-26]. One of the mechanisms of tumor resistance to cisplatin is increased NER

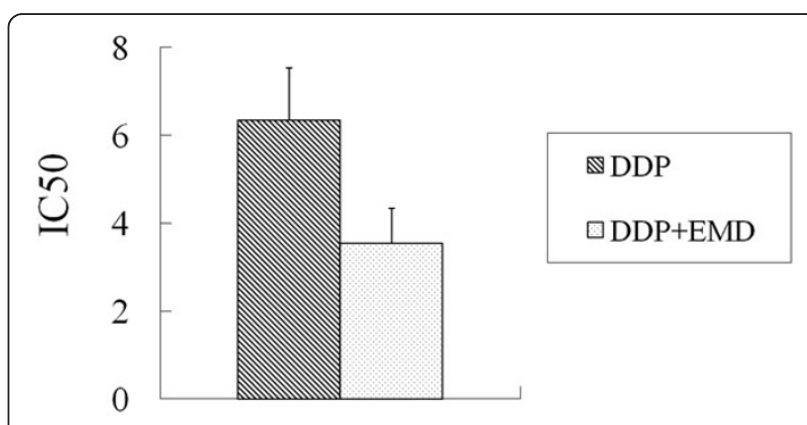

Figure 5 The IC50 of DDP with and without emodin for MCF-7/ Adr cells DDP: Cisplatin 


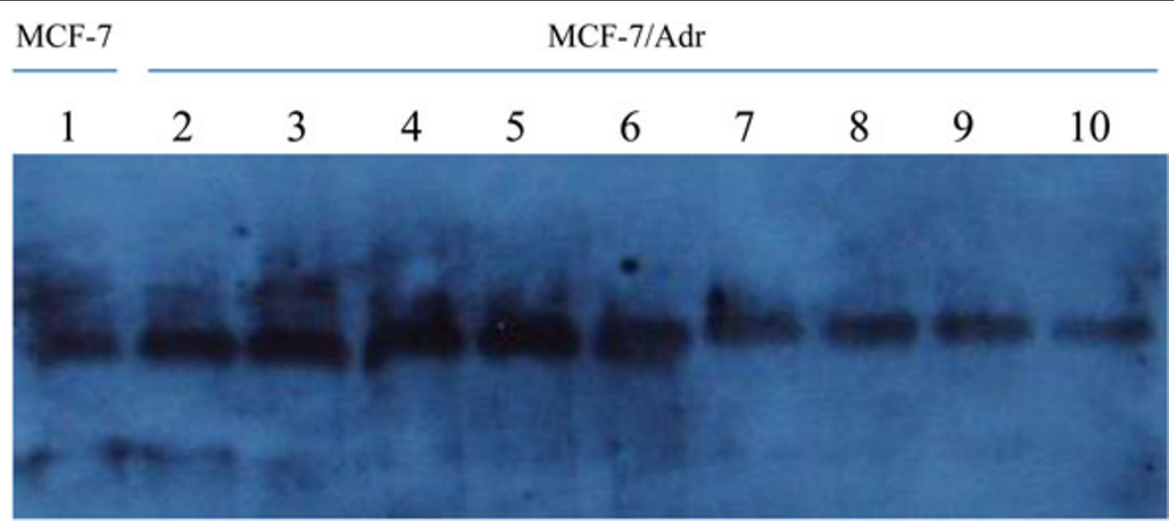

Figure 6 Western blotting results Lane 1: Negative/loading control; lane 2: Blank control; lane 3, 5, 7, 9: Cells exposed to 10 $\mathrm{\mu g} / \mathrm{ml}$ EMD; lane 4, 6, 8, 10: Cells exposed to $20 \mu \mathrm{g} / \mathrm{ml}$ EMD

activity, in particular increased levels of ERCC1, which is a key gene involved in NER of damaged DNA by ultraviolet radiation or chemical agents. The 5 ' incision made by the ERCC1-XPF complex was deemed as a rate-limiting step in the NER pathway, as shown by an increase in excision activity in extracts from non-cisplatin resistant cells after addition of purified ERCC1-XPF protein, compared with no increase in excision activity after addition of ERCC1-XPF to extracts from cisplatin-resistant cells $[27,28]$. The potential use of ERCC1 mRNA expression as a predictive marker for the effectiveness of cisplatin-based chemotherapy is an important area of clinical research [29].

Patients with lower DNA repair capacity are more chemosensitive than those who carry a proficient DNA repair system. In early, it was shown that elevated DNA repair capacity is associated with drug resistance in lung cancer cell lines [30], and it was suggested that modulation of DNA repair mechanisms, such as the incorporation of specific DNA repair inhibitors in therapeutic regimens. Although low expression of ERCC1 is related to carcinogenesis, high expression could enhance the NER, leading to rapid repair of the damaged tumor DNA after chemotherapy, a plausible mechanism of multi-drug resistance in many cancers [31]. Thus, we processed a serial studies about ERCC1 in breast cancer and look for novel anti-cancer strategies to avoid drug resistance and improve treatment outcomes.

EMD is a chemical compound of the anthraquinone family mainly derived from the root of Rheum palmatum, a widely used herb in traditional Chinese medicine, with a variety of anti-bacteria, anti-tumor and anti-constipation properties. Studies at the cellular level have shown that EMD affects cell proliferation by inhibiting DNA synthesis, prolonging the cell cycle duration, and suppressing mitosis. In our study, when the two breast cancer cells were exposed to $0 \sim 120 \mu \mathrm{g} / \mathrm{ml}$ of EMD, the
IC50 was $100 \pm 0.35 \mu \mathrm{g} / \mathrm{ml}$ for MCF-7 and $79 \pm$ $0.28 \mu \mathrm{g} / \mathrm{ml}$ for MCF-7/Adr. At $20 \mu \mathrm{g} / \mathrm{ml}$ EMD, cell viability was over $85 \%$ for both MCF-7 and MCF-7/Adr. Therefore, we selected $10 \mu \mathrm{g} / \mathrm{ml}$ EMD at which no cell growth inhibition was observed as the starting dose for the reversal test. Our results showed that in MCF-7/Adr cells, EMD could reduce the ADM-resistance by 2.86 folds, and the DDP resistance was reduced by 1.79 folds. These results confirm that EMD is a highly effective drug-resistance reversal agent with low toxicity.

High expression of NER repairing ability enhancement is considered as one of the mechanisms of tumor drug resistance [32,33]. In this study, two concentrations of emodin, $20 \mu \mathrm{g} / \mathrm{mL}$ and $10 \mu \mathrm{g} / \mathrm{mL}$, were used to deal with low toxicity concentration MCF-7/Adr cell line, in 2, 4, 6 and10 days and the expression of ERCC1 protein was examined by Western blotting. The results showed higher levels of ERCC1 protein expression in MCF-7/Adr cell lines than in MCF-7 ones, but after emodin treatment, the ERCC1 protein levels decreased further and is significantly time-dependent and possibly dose-dependent as greater inhibitory effect was observed in the concentration of $20 \mu \mathrm{g} / \mathrm{ml}$. Given that only two concentration were studied, it may still have a certain concentration range to explore further the true dose-effect relationship.

Many new anti-cancer agents is being developed in recent years, but many studies have now focused on the reversal of chemoresistance in tumor in order to maximize the treatment capacity of existing chemotherapeutic agents. Some medicinal herbs may hold great potential in this field. This in vitro study found that EMD can significantly reverse the multi-drug resistance and reduce ERCC1 expression in breast cancer cells. Further studies are warranted to explore how ERCC1 plays role in reversing drug resistance and more preclinical evidence is necessary before the use emodin will be studied in clinical trials. 


\section{Conclusions}

In this in vitro study, we noticed that ERCC1 expression might be associated with drug resistance and that emodin might play a possible role of reversing drug resistance. This is a preliminary finding which needs further investigation to explore the use of emodin in breast cancer treatment. However, we must emphasize that with recent advances of molecular biology, breast cancer was categorized into many different molecular subtypes which might possess different characteristics from carcinogenesis to metastasis. Therefore, the study of a single biomarker might be further complicated. Nevertheless, we believe further studies on ERCC1 expression in breast cancer and emodin in facilitating the reversal of drug resistance are warranted.

\section{Acknowledgements}

This article has been published as part of Journal of Translational Medicine Volume 10 Supplement 1, 2012: Selected articles from the Organisation for Oncology and Translational Research (OOTR) 7th Annual Conference. The full contents of the supplement are available online at http://www.translationalmedicine.com/supplements/10/S1.

\section{Author details}

'Department of Breast Disease, Shenzhen Maternity and Child Healthcare Hospital, Southern Medical University, Shenzhen, China. ${ }^{2}$ Organisation for Oncology and Translational Research, Hong Kong and UNIMED Medical Institute, Hong Kong SAR.

\section{Authors' contributions}

$J F, J Z, J S, J X$ and LH carried out the pre-clinical research. JF, AY, WL and LC participated in writing the manuscript. WL performed statistical analysis. JF and LC provided expert opinion for the study. JF was the initiator of the study.

\section{Competing interests}

The author(s) declare that they have no competing interests.

Published: 19 September 2012

\section{References}

1. Fu JM, Zhou J, Xie JJ, Li H: Effect of neoadjuvant chemotherapy on ERCC1 gene expression in breast cancer. J South Med Univ 2008, 28:603-605.

2. Juhasz A, Frankel P, Cheng C, Rivera H, Vishwanath R, Chiu A, Margolin K, Yen Y, Newman EM, Synold T, Wilczynski S, Lenz HJ, Gandara D, Albain KS, Longmate J, Doroshow JH: Quantification of chemotherapeutic target gene mRNA expression in human breast cancer biopsies: comparison of real-time reverse transcription-PCR vs. relative quantification reverse transcription-PCR utilizing DNA sequencer analysis of PCR products. J Clin Lab Anal 2003, 17:184-194.

3. Ferry KV, Hamilton TC, Johnson SW: Increased nucleotide excision repair in cisplatin-resistant ovarian cancer cells: role of ERCC1-XPF. Biochem Pharmacol 2000, 60:1305-1313.

4. Selvakumaran M, Pisarcik DA, Bao R, Yeung AT, Hamilton TC: Enhanced cisplatin cytotoxicity by disturbing the nucleotide excision repair pathway in ovarian cancer cell lines. Cancer Res 2003, 63:1311-1316.

5. Vandenput I, Capoen A, Coenegrachts L, Verbist G, Moerman P, Vergote I, Amant F: Expression of ERCC1, p53, and Class III $\beta$-Tubulin Do Not Reveal Chemoresistance in Endometrial Cancer: Results From an Immunohistochemical Study. Int J Gynecol Cancer 2011, 21:1071-1077.

6. Krivak TC, Darcy KM, Tian C, Bookman M, Gallion H, Ambrosone CB, Deloia JA: Single nucleotide polypmorphisms in ERCC1 are associated with disease progression, and survival in patients with advanced stage ovarian and primary peritoneal carcinoma; a Gynecologic Oncology Group study. Gynecol Oncol 2011, 122:121-126.

7. Roth JA, Carlson JJ: Prognostic Role of ERCC1 in Advanced Non-Small-Cell Lung Cancer: A Systematic Review and Meta-Analysis. Clin Lung Cancer.

8. Tepeli E, Caner V, Büyükpınarbaşılı N, Cetin GO, Düzcan F, Elmas L, Bağ Cı G: Expression of ERCC1 and its clinicopathological correlations in non-small cell lung cancer. Mol Biol Rep

9. Tsai MS, Weng SH, Kuo YH, Chiu YF, Lin YW: Synergistic effect of curcumin and cisplatin via down-regulation of thymidine phosphorylase and excision repair cross-complementary 1 (ERCC1). Mol Pharmacol 2011, 80:136-146.

10. Sun JM, Ahn MJ, Park MJ, Lee HY, Ahn JS, Lee S, Kang G, Han J, Son YI, Baek CH, Ahn YC, Park K: Expression of excision repair crosscomplementation group 1 as predictive marker for nasopharyngeal cancer treated with concurrent chemoradiotherapy. Int J Radiat Oncol Biol Phys 2011, 80:655-660.

11. Kaira K, Serizawa M, Koh Y, Miura S, Kaira R, Abe M, Nakagawa K, Ohde Y, Okumura T, Naito T, Murakami H, Takahashi T, Kondo H, Nakajima T, Endo $M$, Yamamoto $\mathrm{N}$ : Expression of excision repair crosscomplementation group 1 , breast cancer susceptibility 1 , and $\beta$ IIItubulin in thymic epithelial tumors. J Thorac Oncol 2011, 6:606-613.

12. Knez L, Sodja E, Kern I, Košnik M, Cufer T: Predictive value of multidrug resistance proteins, topoisomerases II and ERCC1 in small cell lung cancer: a systematic review. Lung Cancer 2011, 72:271-279.

13. Kim D, Jung W, Koo JS: The expression of ERCC1, RRM1, and BRCA1 in breast cancer according to the immunohistochemical phenotypes. J Korean Med Sci 2011, 26:352-359.

14. Huang Z, Chen G, Shi P: Emodin-induced apoptosis in human breast cancer BCap-37 cells through the mitochondrial signaling pathway. Arch Pharm Res 2008, 31:742-748.

15. Jing X, Ueki N, Cheng J, Imanishi H, Hada T: Induction of apoptosis in hepatocellular carcinoma cell lines by emodin. Jpn J Cancer Res 2002, 93:874-882.

16. Zhang L, Lau YK, Xia W, Hortobagyi GN, Hung MC: Tyrosine kinase inhibitor emodin suppresses growth of HER-2/neu-overexpressing breast cancer cells in athymic mice and sensitizes these cells to the inhibitory effect of paclitaxel. Clin Cancer Res 1999, 5:343-353.

17. Jiang XF, Zhen YS: Reversal of multidrug resistance by emodin in cancer cells. Acta Pharmaceutica Sinica 1999, 34:164-167.

18. Fu ZY, Han JX, Huang HY: Effects of emodin on gene expression profile in small cell lung cancer $\mathrm{NCl}-\mathrm{H} 446$ cell. Chin Med J (Engl) 2007, 120:1710-1715.

19. Falo C, Moreno A, Varela M, Lloveras B, Figueras A, Escobedo A: HER-2/neu status and response to CMF: retrospective study in a series of operable breast cancer treated with primary CMF chemotherapy. J Cancer Res Clin Oncol 2007, 133:423-429.

20. Gan HZ, Zhang GZ, Zhao JS, Zhang FC, Bu LS, Yang SJ, Piao SL, Du ZW, Gao S, Zheng DM: Reversal of MDR1 gene-dependent multidrug resistance using short hairpin RNA expression vectors. Chin Med J (Engl) 2005, 118:893-902.

21. Rosell R, Felip E, Paz-Ares L: How could pharmacogenomics help improve patient survival? Lung Cancer 2007, 57(Suppl 2):S35-S41.

22. Geyer FC, Weigelt B, Natrajan R, Lambros MB, de Biase D, Vatcheva R, Savage K, Mackay A, Ashworth A, Reis-Filho JS: Molecular analysis reveals a genetic basis for the phenotypic diversity of metaplastic breast carcinomas. J Pathol 2010, 220:562-573.

23. Li WT, Zhou GY, Wang CL, Guo CH, Song XR, Chi WL: Modulation of breast cancer resistance protein mediated atypical multidrug resistance using RNA interference delivered by adenovirus. Chin Med J (Engl) 2005, 118:1123-1126.

24. Burness ML, Grushko TA, Olopade Ol: Epidermal growth factor receptor in triple-negative and basal-like breast cancer: promising clinical target or only a marker? Cancer J 2010, 16:23-32.

25. Rosell R, Moran T, Fernanda Salazar M, Mendez P, De Aguirre I, Ramirez JL, Isla D, Cobo M, Camps C, Lopez-Vivanco G, Alberola V, Taron M: The place of targeted therapies in the management of non-small cell bronchial carcinoma. Molecular markers as predictors of tumor response and survival in lung cancer. Rev Mal Respir 2006, 23:16S131-16S136.

26. Yao GY, Zhou JL, Zhao ZS, Ruan J: Biological characteristics of breast carcinomas with neuroendocrine cell differentiation. Chin Med J (Engl) 2004, 117:1536-1540. 
27. Zhou W, Liu G, Park S, Wang Z, Wain JC, Lynch TJ, Su L, Christiani DC: Gene-smoking interaction associations for the ERCC1 polymorphisms in the risk of lung cancer. Cancer Epidemiol Biomarkers Prev 2005, 14:491-496.

28. Olaussen KA, Dunant A, Fouret P, Brambilla E, André F, Haddad V, Taranchon E, Filipits M, Pirker R, Popper HH, Stahel R, Sabatier L, Pignon JP, Tursz T, Le Chevalier T, Soria JC, IALT Bio Investigators: DNA repair by ERCC1 in non-small-cell lung cancer and cisplatin-based adjuvant chemotherapy. N Engl J Med 2006, 355:983-991.

29. Wachters FM, Wong LS, Timens W, Kampinga HH, Groen HJ: ERCC1, hRad51, and BRCA1 protein expression in relation to tumour response and survival of stage III/IV NSCLC patients treated with chemotherapy. Lung Cancer 2005, 50:211-219.

30. Zeng-Rong N, Paterson J, Alpert L, Tsao MS, Viallet J, Alaoui-Jamali MA: Elevated DNA repair capacity is associated with intrinsic resistance of lung cancer to chemotherapy. Cancer Res 1995, 55:4760-4764.

31. Vilmar A, Sørensen JB: Excision repair cross-complementation group 1 (ERCC1) in platinum-based treatment of non-small cell lung cancer with special emphasis on carboplatin: a review of current literature. Lung Cancer 2009, 64:131-139.

32. Joyce EF, Tanneti SN, McKim KS: Drosophila hold'em is required for a subset of meiotic crossovers and interacts with the dna repair endonuclease complex subunits MEI-9 and ERCC1. Genetics 2009, 181:335-340

33. Bhargava R, Beriwal S, Dabbs DJ, Ozbek U, Soran A, Johnson RR, Brufsky AM, Lembersky BC, Ahrendt GM: Immunohistochemical surrogate markers of breast cancer molecular classes predicts response to neoadjuvant chemotherapy: a single institutional experience with 359 cases. Cancer 2010, 116:1431-1439, Erratum in: Cancer 2011, 117:2238.

doi:10.1186/1479-5876-10-S1-S7

Cite this article as: Fu et al:: Emodin affects ERCC1 expression in breast cancer cells. Journal of Translational Medicine 2012 10(Suppl 1):S7.

\section{Submit your next manuscript to BioMed Central and take full advantage of:}

- Convenient online submission

- Thorough peer review

- No space constraints or color figure charges

- Immediate publication on acceptance

- Inclusion in PubMed, CAS, Scopus and Google Scholar

- Research which is freely available for redistribution

Submit your manuscript at www.biomedcentral.com/submit 